\title{
Model analysis of the factors regulating the trends and variability of carbon monoxide between 1988 and 1997
}

\author{
B. N. Duncan ${ }^{1,2}$ and J. A. $\operatorname{Logan}^{3}$ \\ ${ }^{1}$ Goddard Earth Sciences and Technology Center, University of Maryland at Baltimore County, Baltimore, MD, USA \\ ${ }^{2}$ NASA Goddard Space Flight Center, Code 613.3, Greenbelt, MD, USA \\ ${ }^{3}$ School of Engineering and Applied Sciences, Harvard University, Cambridge, MA, USA
}

Received: 9 April 2008 - Published in Atmos. Chem. Phys. Discuss.: 20 May 2008

Revised: 18 November 2008 - Accepted: 18 November 2008 - Published: 12 December 2008

\begin{abstract}
We used a 3-D model of chemistry and transport to investigate trends and variability in tropospheric carbon monoxide (CO) for 1988-1997 caused by changes in the overhead ozone column, fossil fuel emissions, biomass burning emissions, methane, and transport. We found that the decreasing $\mathrm{CO}$ burden in the northern extra-tropics $(-0.85 \% / \mathrm{y})$ was more heavily influenced by the decrease in European emissions during our study period than by the similar increase in Asian emissions, as transport pathways from Europe favored accumulation at higher latitudes in winter and spring. However, the opposite trends in the CO burdens from these two source regions counterbalanced at lower latitudes. Elsewhere, the factors influencing CO often compete, diminishing their cumulative impact, and trends in model $\mathrm{CO}$ were small or insignificant for our study period, except in the tropics in boreal fall $(1.1 \% / y)$, a result of emissions from major fires in Indonesia late in 1997. There was a decrease in the ozone column during the study period as a result of the phase of the solar cycle and the eruption of Pinatubo in 1991. This decrease contributed negatively to the trend in model $\mathrm{CO}$ by increasing the hydroxyl radical $(\mathrm{OH})$. The impact of this negative contribution was diminished by a positive contribution of similar magnitude from increasing methane. However, the trends in these two factors did not cancel for tropospheric $\mathrm{OH}$, which responded primarily to changes in the ozone column.
\end{abstract}

\section{Introduction}

The oxidizing capacity of the troposphere depends on trends and variability in carbon monoxide (CO), the main sink for the hydroxyl radical $(\mathrm{OH})$ which is the primary tropospheric

Correspondence to: B. N. Duncan

(bryan.n.duncan@nasa.gov) oxidant. In this study we explore the causes of trends (or lack thereof) of CO for 1988-1997. There were relatively large trends in fossil fuel emissions of $\mathrm{CO}$ in Asia and $\mathrm{Eu}-$ rope during this period, as well as several large biomass burning events that contributed to regional trends and interannual variability (IAV) in CO. The eruption of Mt. Pinatubo in 1991 caused variations in tropospheric $\mathrm{OH}$ and subsequently $\mathrm{CO}$ for a few years. We deconvolve the impacts on $\mathrm{CO}$ of trends in fossil fuel emissions, biomass burning, methane concentrations, and the ozone column with a series of sensitivity simulations using the tropospheric 3-D chemistry and transport model (CTM) described in Duncan et al. (2007).

During the 1980s and 1990s there was an expansion of the routine measurements of $\mathrm{CO}$, especially surface observations from the flask sampling program of the National Oceanic and Atmospheric Administration (NOAA) Earth System Research Laboratory, Global Monitoring Division (GMD) (Novelli et al., 1992). The total column of CO is also measured at several locations around the world, with data collected at a few sites since the 1970s (Zander et al., 1989; Yurganov et al., 1997; Mahieu et al., 1997; Zhao et al., 2000; Rinsland et al., 1998, 1999, 2000). This database provides the means with which to derive trends in observed $\mathrm{CO}$ and to evaluate model performance.

There were few systematic measurements of $\mathrm{CO}$ before the late 1980s. The data suggest that CO was increasing at about 1\%/y in the Northern Hemisphere (NH) (Khalil and Rasmussen, 1988; Zander et al., 1989; Yurganov et al., 1999), probably because of increasing anthropogenic emissions (Novelli et al., 1998). By the end of the 1980s, this upward trend was replaced by a downward trend (Khalil and Rasmussen, 1994; Novelli et al., 1994). There were sparse measurements in the Southern Hemisphere (SH) before the 1990s. Surface data from Cape Point, South Africa, suggest no trend for 1979-1987 (Brunke et al., 1990).

Published by Copernicus Publications on behalf of the European Geosciences Union. 
Table 1. Direct emissions (Tg CO) from fossil fuel fources by region.

\begin{tabular}{crrrrrr}
\hline & Year & Europe $^{1}$ & $\begin{array}{r}\text { North } \\
\text { America }^{2}\end{array}$ & $\begin{array}{r}\text { East } \\
\text { Asia }^{3}\end{array}$ & $\begin{array}{r}\text { Rest } \\
\text { of World }\end{array}$ & Globe \\
\hline Emissions & 88 & 148 & 111 & 102 & 50 & 411 \\
& 92 & 120 & 96 & 125 & 58 & 399 \\
& 97 & 90 & 93 & 155 & 66 & 404 \\
$\Delta$ Emissions & $97-88$ & -58 & -18 & +53 & +16 & -7 \\
Ratio & $97 / 88$ & 0.61 & 0.84 & 1.52 & 1.32 & 0.98 \\
\hline
\end{tabular}

${ }^{1} 38^{\circ} \mathrm{N}-70^{\circ} \mathrm{N} ; 15^{\circ} \mathrm{W}-78^{\circ} \mathrm{E}$ and $52^{\circ} \mathrm{N}-70^{\circ} \mathrm{N} ; 75^{\circ} \mathrm{E}-180^{\circ} \mathrm{E} .{ }^{2} 28^{\circ} \mathrm{N}-70^{\circ} \mathrm{N} ; 170^{\circ} \mathrm{W}-50^{\circ} \mathrm{W} .{ }^{3} 8^{\circ} \mathrm{N}-44^{\circ} \mathrm{N} ; 75^{\circ} \mathrm{E}-150^{\circ} \mathrm{E}$.

Novelli et al. (2003) reported that global surface CO decreased by $0.52 \mathrm{ppbv} / \mathrm{y}$ between 1991 and 2001, with $\sim 30 \%$ of that decline being attributed to the aftermath of the eruption of Mt. Pinatubo (June 1991), and the subsequent increase in tropospheric OH (Bekki et al., 1994; Novelli et al., 1994; Dlugokencky et al., 1996, 1998). The remainder of the decline was caused by the decrease in anthropogenic emissions in the $\mathrm{NH}$, where $\mathrm{CO}$ decreased by $1.4 \mathrm{ppbv} / \mathrm{y}$ in the northern extra-tropics. Novelli et al. (2003) found no significant trend in the $\mathrm{SH}$, though there was IAV associated with variations in biomass burning emissions.

We describe briefly the formulation and evaluation of the model in Sect. 2; further details are given in Duncan et al. (2007). In Sect. 3, we discuss the trends in the dominant factors with the potential to influence trends in $\mathrm{CO}$ and $\mathrm{OH}$ (i.e., overhead ozone column, fossil fuel emissions, biomass burning emissions, transport and methane). In Sect. 4, we present the trends in model CO. In Sect. 5, we analyze the causes of $\mathrm{CO}$ trends and variability. A summary of our results is given in Sect. 6 .

\section{Model and simulation description}

\subsection{Model framework}

In our earlier paper (Duncan et al., 2007) we described and evaluated the version of the GEOS-Chem CTM that we use here, so we only provide a brief description. The model is driven by assimilated meteorological data, capturing variations in $\mathrm{CO}$ caused by IAV in transport. The model captures feedbacks between $\mathrm{CO}$ and $\mathrm{OH}$ by using a chemical parameterization scheme that allows $\mathrm{OH}$ to respond to changes in the concentrations of trace gases, meteorology, and the overhead ozone column (Duncan et al., 2000). We use the merged data set of Stolarski and Firth (2006) to account for IAV in the ozone column. It is derived from measurements by the Total Ozone Mapping Spectrometer/Solar Backscatter Ultraviolet (TOMS/SBUV) instruments.
The sources of $\mathrm{CO}$ include direct emissions from biomass burning, fossil fuel and biofuel combustion, and chemical production from the oxidation of methane and biogenic and anthropogenic non-methane hydrocarbons (NMHC). These sources are discussed in detail Sect. 3 of Duncan et al. (2007) and are summarized in Table 1 of that paper. The annual variations in emissions from fossil fuel combustion are based on national inventories where available and on statistics for liquid fuel use (Bey et al., 2001a; Duncan et al., 2007). The total annual biomass burned inventory used in this study is described in Lobert et al. (1999), with CO emissions summarized in Duncan et al. (2003a); the IAV in biomass burning is estimated using the TOMS Aerosol Index as a surrogate. Emissions from biofuels are described by Yevich et al. (2003). We account for the production of CO from the oxidation of methane assuming a yield of $1 \mathrm{CO}$ per methane oxidized as discussed in Duncan et al. (2007). The production of $\mathrm{CO}$ from $\mathrm{NMHC}$ is estimated by converting the emissions of NMHC to CO by applying a yield of CO per NMHC oxidized as recommended by Altshuller (1991). Uncertainties in the budget of CO for 1988-1997 are discussed in Duncan et al. (2007).

We used version 5.02 of the GEOS-Chem model for transport (http://www-as.harvard.edu/chemistry/trop). The transport is driven by assimilated meteorology from the Goddard Earth Observing System Global Modeling and Assimilation Office (GEOS GMAO) (Schubert et al., 1993; Takacs et al., 1994). We use GEOS-1 fields from January 1988 to November 1995, and GEOS-Strat fields from December 1995 to December 1997. The sigma vertical levels of the model are given in Bey et al. (2001a). All meteorological data were regridded from a resolution of $2^{\circ} \times 2.5^{\circ}$ (latitude by longitude) to $4^{\circ} \times 5^{\circ}$.

\subsection{Model simulations}

We discuss seven simulations. The first is our Standard run and the second tracks CO tracers tagged as a function of their source: both are described in Duncan et al. (2007). We 
use the other simulations to quantify the contributions from trends in the ozone column, fossil fuel emissions, biomass burning emissions, transport, and methane to trends in $\mathrm{CO}$ and in $\mathrm{OH}$ in the Standard simulation. In each, we fix one of these factors to its values for 1988 for the entire simulation, while allowing the others to vary.

\subsection{Model evaluation}

A detailed evaluation of model $\mathrm{CO}$ with observations is presented in Duncan et al. (2007). We compared model CO to observations from the NOAA/GMD flask sampling program, $\mathrm{CO}$ column observations, and profiles from various aircraft campaigns. The evaluation shows that the main features of the spatial and seasonal variations of $\mathrm{CO}$ are reproduced well by the model implying that the magnitude and timing of the emissions are reasonable. The model reproduces the $20 \%$ decrease in CO observed at high NH latitudes 1988-1997 and the $10 \%$ decrease in the North Pacific, caused primarily by a decrease in European emissions as discussed below. The model is too low at the seasonal maximum in spring in the southern tropics, except for locations in the Atlantic Ocean. This problem may be caused by an overestimate of the frequency of tropical deep convection, as discussed in Duncan et al. (2007).

\section{Trends in causal factors}

\subsection{Fossil fuel emissions}

There were strong regional trends in fossil fuel emissions for 1988-1997 as shown in Fig. 2 of Duncan et al. (2007). Table 1 presents the emissions for fossil fuels by region for several years. European emissions decreased 39\% from 1988 to 1997 , from $148 \mathrm{Tg}$ to $90 \mathrm{Tg} \mathrm{CO}$. Emissions in Western Europe decreased by $33 \%$ (61 Tg to $41 \mathrm{Tg}$ ), mostly through regulatory controls, while in Eastern Europe $\left(>22^{\circ} \mathrm{E}\right)$ they decreased by $45 \%$ ( $87 \mathrm{Tg}$ to $48 \mathrm{Tg}$ ) because of the economic contraction following the breakup of the former Soviet Union. At the same time, the countries of East Asia, especially China, underwent an unprecedented economic expansion, increasing emissions by $52 \%$ (102 $\mathrm{Tg}$ to $155 \mathrm{Tg}$ ). The decrease in emissions from North America was smaller, $16 \%$ (111 Tg to $93 \mathrm{Tg}$ ). The decrease of emissions in Europe, $-58 \mathrm{Tg}$, was approximately counterbalanced by the increase in emissions from East Asia, $+53 \mathrm{Tg}$. Relatively small increases (16 Tg) occurred elsewhere, primarily in Latin America $(7 \mathrm{Tg})$ and Africa (6 Tg). Overall total fossil fuel emissions from the $\mathrm{NH}$ decreased only by $4 \%$, or $14 \mathrm{Tg} \mathrm{CO}$, for 1988-1997, despite the strong regional trends.

\subsection{Overhead ozone column}

Figure 1 shows the deviation (\%) of the monthly mean ozone column from the monthly means for 1979-2006 using the merged data set of Stolarski and Frith (2006). During our study period, 1988-1997, the ozone column was strongly impacted by the eruption of Mt. Pinatubo in June 1991 (WMO, 2007). Substantial ozone loss occurred after the eruption of Mt. Pinatubo, especially in the NH mid-latitudes. Hydrolysis of $\mathrm{N}_{2} \mathrm{O}_{5}$ on sulfate aerosols in the lower stratosphere effectively sequestered NO allowing enhanced catalytic destruction of ozone by chlorine (Mickley et al., 1997). The ozone column also depends on natural sources of variability, including the solar cycle and quasi-biennial oscillation (QBO).

We calculate trends in ozone with the multivariate linear regression model of Ziemke et al. (1997), except that we do not include terms to remove the dependence of ozone on the solar cycle and the QBO. Such regression models usually include these terms to remove the effects of natural variability on column ozone, in order to compute trends attributable to changes in chlorine and bromine. Our purpose is different however. We are interested in the trend in ozone for 1988-1997, whatever the cause, as this is what impacts tropospheric $\mathrm{OH}$ and, subsequently, $\mathrm{CO}$. There are significant downward trends in all seasons for all four zonal bands for 1988-1997 as shown in Fig. 1. Our study period begins near the peak of a solar cycle and ends near a minimum (e.g., sunspot activity in Fig. 1 as a proxy), and much of the trend in the tropics is caused by the dependence of ozone on the solar cycle.

\subsection{Biomass burning emissions}

Duncan et al. (2003a) found that there were no large-scale trends in biomass burning in the tropics/subtropics for the 1980s and 1990s, but there was significant IAV. Wotawa et al. (2001) found that $63 \%$ of the IAV of summertime CO above $30^{\circ} \mathrm{N}$ can be explained by IAV in boreal forest fires in the high, NH latitudes. Biomass burning is highly seasonal, with some episodic and sometimes extreme events that occur in regions with high biomass loads (i.e., boreal forests and Indonesian forests underlain by peat). The boreal forests of North America experienced unusually large fires in 1994 and 1995, and Indonesia experienced fires in 1991, 1994, and 1997; those in 1997 were particularly severe, releasing an estimated $130 \mathrm{Tg}$ CO (Duncan et al., 2003a, 2003b).

\subsection{Methane}

The source of $\mathrm{CO}$ from methane oxidation is about one-third of the total source of CO (e.g., Holloway et al., 2000; Duncan et al., 2007). Dlugokencky et al. (1998) derived an average trend in the global methane burden of $8.9 \pm 0.1 \mathrm{ppbv} / \mathrm{y}$ for 1984-1996 from GMD surface observations growth, with a decrease in the growth rate of $0.9 \pm 0.1 \mathrm{ppbv} / \mathrm{y}$. We use the GMD measurements to give annually and zonally-averaged mixing ratios for four zonal bands of equal area in the model. The trends in methane are similar in each band for 19881997 , about $+0.4 \% / y$. 

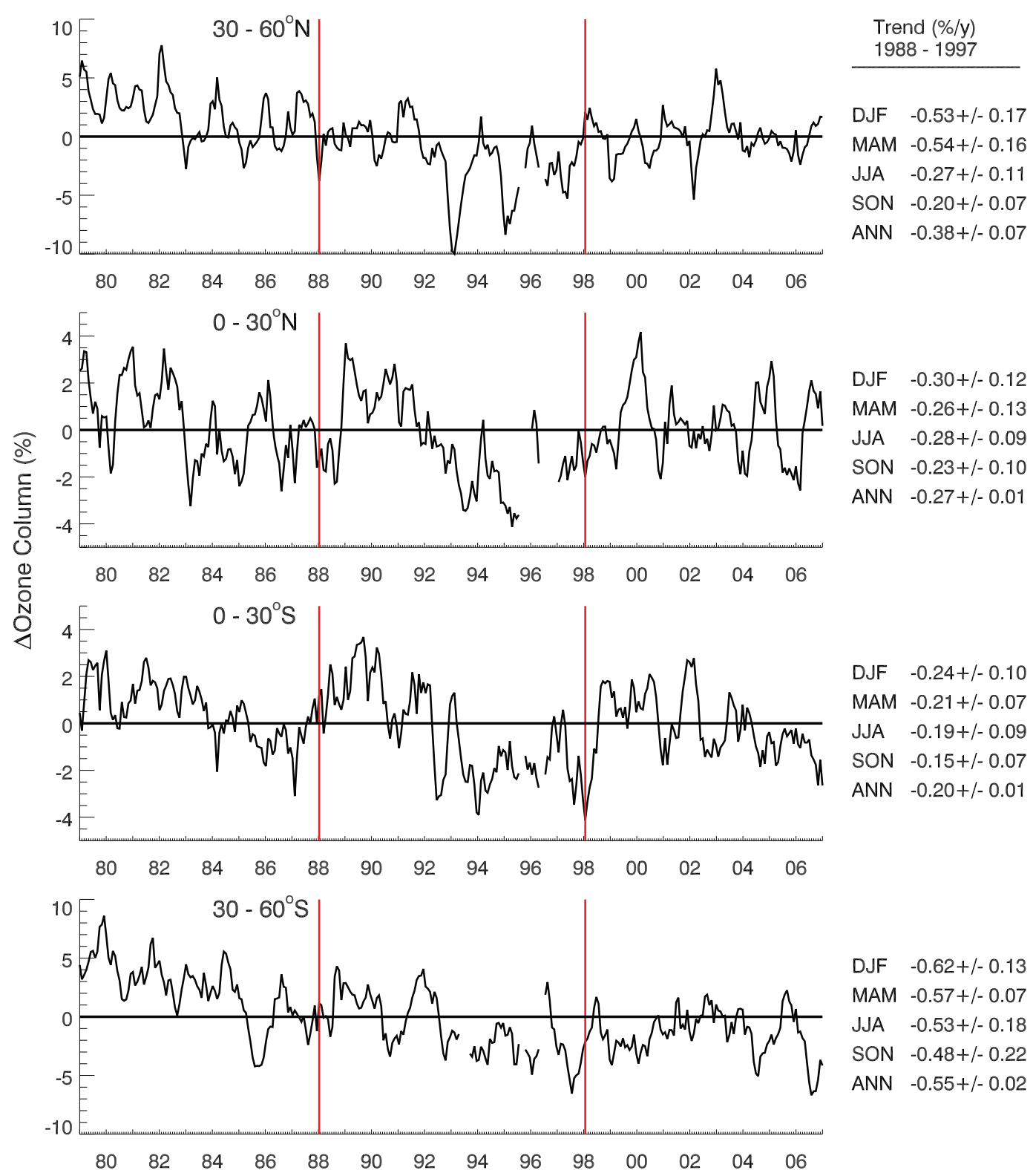

DJF $-0.62+/-0.13$

MAM $-0.57+/-0.07$

JJA $-0.53+/-0.18$

SON $-0.48+/-0.22$

ANN $-0.55+/-0.02$

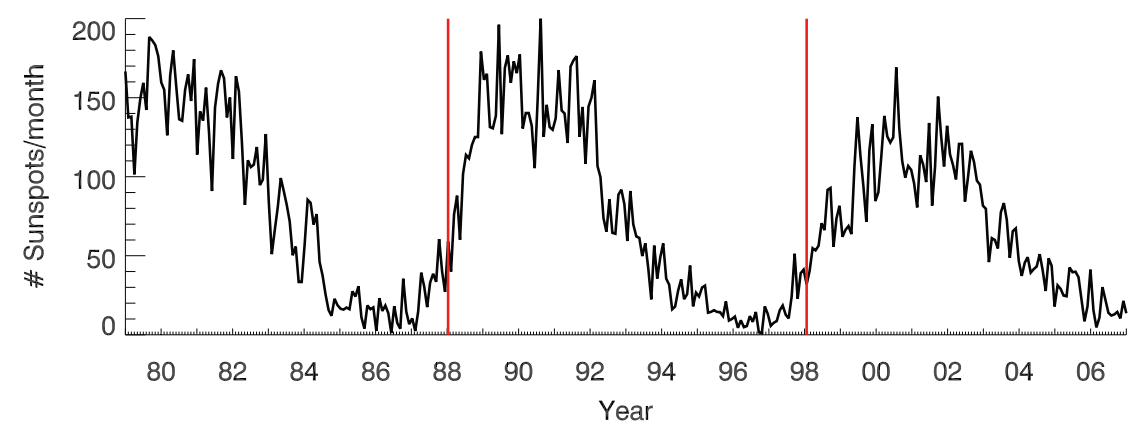

Fig. 1. The top four panels show the change in the observed $\mathrm{O}_{3}$ column $(\%)$ for 1979-2006 relative to the monthly mean column for 19792006 for four zonal bands. The time period of our study, 1988-1997, is shown between red vertical lines; the annual and seasonal observed trends $(\% / y)$ are shown at right. The trends have the effects of the seasonal cycle removed. DJF=December-February; MAM=March-May; JJA=June-August; SON=September-November; ANN=January-December. The bottom panel shows the monthly number of sunspots/month for 1979-2006, a proxy for the solar cycle. 


\subsection{Transport}

Changes in atmospheric circulation caused by the El Niño/Southern Oscillation (ENSO) can be substantial, impacting many regions of the world (Lau and Yang, 2002). Our study period includes the most extreme ENSO event of the century that occurred in 1997-1998 (Bell and Halpert, 1998; Glantz, 2001) and the weaker, prolonged ENSO event of 1990-1995 (Allan and D'Arrigo, 1999). Only two periods, 1988-early 1989 and early 1996, experienced La Niña conditions, with the 1996 event being weak. By chance, our study period began with an unusually strong La Niña and ended with an unusually strong El Niño.

In the extra-tropics of the NH, the North Atlantic Oscillation (NAO) is one of the dominant influences on climate variability from eastern North America to Siberia, especially during winter (Hurrell et al., 2002). Duncan and Bey (2004) showed that IAV of the NAO caused variations in surface CO over Europe, effectively masking the influence of the downward trend in European fossil fuel emissions for 1987-1997.

\subsection{Other factors}

Trends and variability in emissions of $\mathrm{NO}_{\mathrm{x}}$ and $\mathrm{NMHC}$, and in tropospheric ozone may impact $\mathrm{OH}$ and hence $\mathrm{CO}$. As discussed in Duncan et al. (2007), we use the monthly-averaged distributions (1988-1997) from the GEOS-Chem simulation with the kinetic solver presented in Duncan and Bey (2004) as input to this simulation which uses the parameterization method to calculate $\mathrm{OH}$. These fields, and subsequently their impact on $\mathrm{OH}$, already account for variations of transport, emissions, the overhead ozone columns, etc.

We use a linear scaling of the direct emissions of $\mathrm{CO}$ to account for $\mathrm{CO}$ from the oxidation of anthropogenic NMHC (Duncan et al., 2007), so this source of CO is not an independent cause of variability in our simulation. We estimate the production of $\mathrm{CO}$ from biogenic NMHC oxidation, which is a function of temperature, sunlight, and/or $\mathrm{NO}_{\mathrm{x}}$ as described in Duncan et al. (2007); this source of CO varies annually by $6 \%$ during the study period (or by less than $1 \%$ of the total CO source).

The use of the two meteorological fields may contribute a spurious component to any calculated trend even though the model versions are similar (except for the number of levels in the stratosphere). Therefore, we show trends for both 1988-1997 and 1988-1995 in Sect. 5, but our conclusions are not dependent on the ending year of our analysis. Any spurious components are dwarfed because of real variations in the causal factors described in Sect. 3.1-3.5, which explain the majority $(>80 \%)$ of variation in the total $\mathrm{CO}$ trends (see Sect. 5).

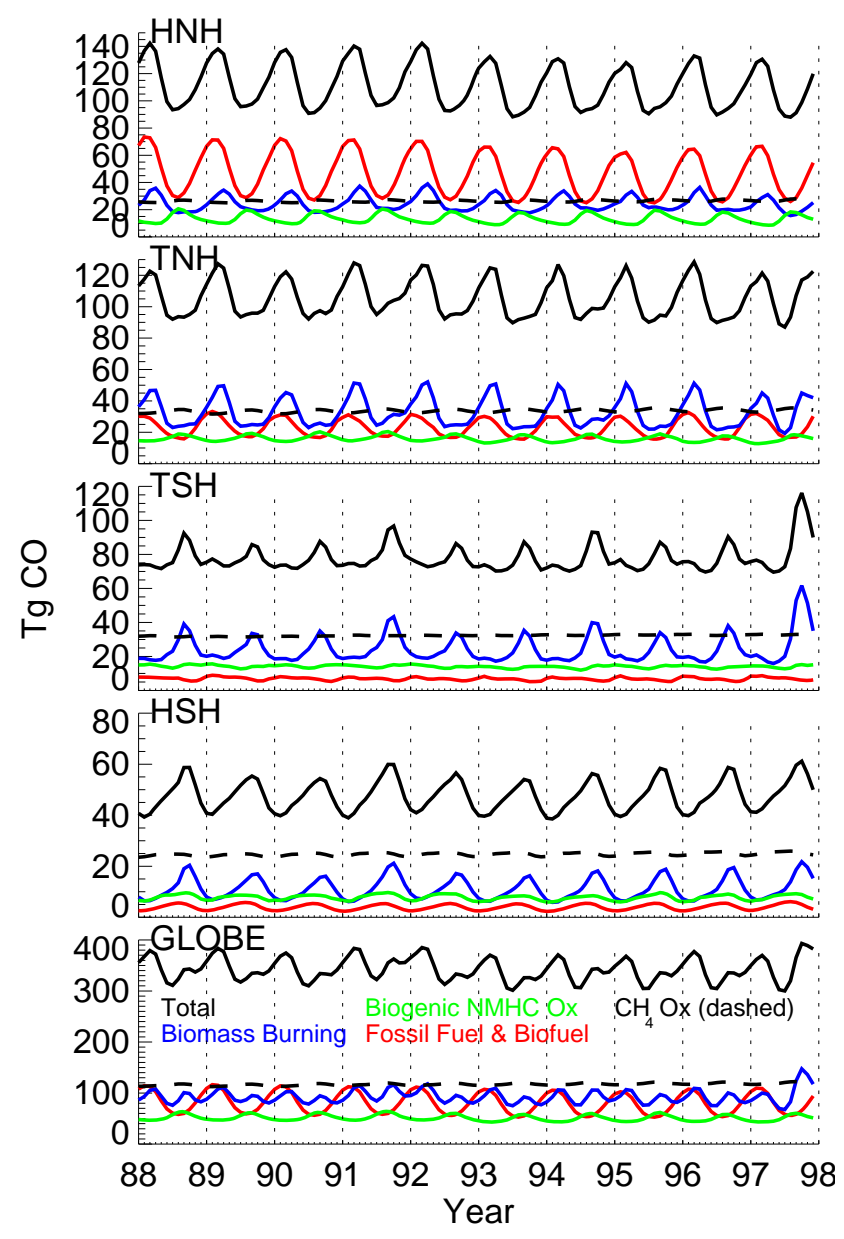

Fig. 2. Monthly tropospheric burden of $\mathrm{CO}(\mathrm{Tg})$ by source.

\section{Trends in Model CO}

We discuss the burden and trends in model $\mathrm{CO}$ for four latitude bands: $30-90^{\circ} \mathrm{N}(\mathrm{HNH}$, high $\mathrm{NH}), 0^{\circ}-30^{\circ} \mathrm{N}(\mathrm{TNH}$, tropical and subtropical $\mathrm{NH}), 0^{\circ}-30^{\circ} \mathrm{S}(\mathrm{TSH})$, and $30-90^{\circ} \mathrm{S}$ (HSH). Although there is heterogeneity within each band, the factors that influence the distributions and trends are different enough to warrant this artificial demarcation. Except in the extra-tropics in winter, the lifetime of CO is typically short in relation to meridional mixing so that a trend in one of our zonal bands may not necessarily affect the trend in another (Khalil and Rasmussen, 1994). Unless otherwise specified, we compute trends using the method presented in Ziemke et al. (1997).

Figure 2 shows the tropospheric burden of CO by source (i.e., methane oxidation, fossil fuels and biofuels, biomass burning, and biogenic NMHC oxidation) for 1988-1997. The production of $\mathrm{CO}$ from methane oxidation is $\sim 35 \%$ of the total tropospheric source and contributes a similar fraction, about $100-120 \mathrm{Tg} \mathrm{CO}$, to the total burden. The global burden from biomass burning shows two peaks each year 


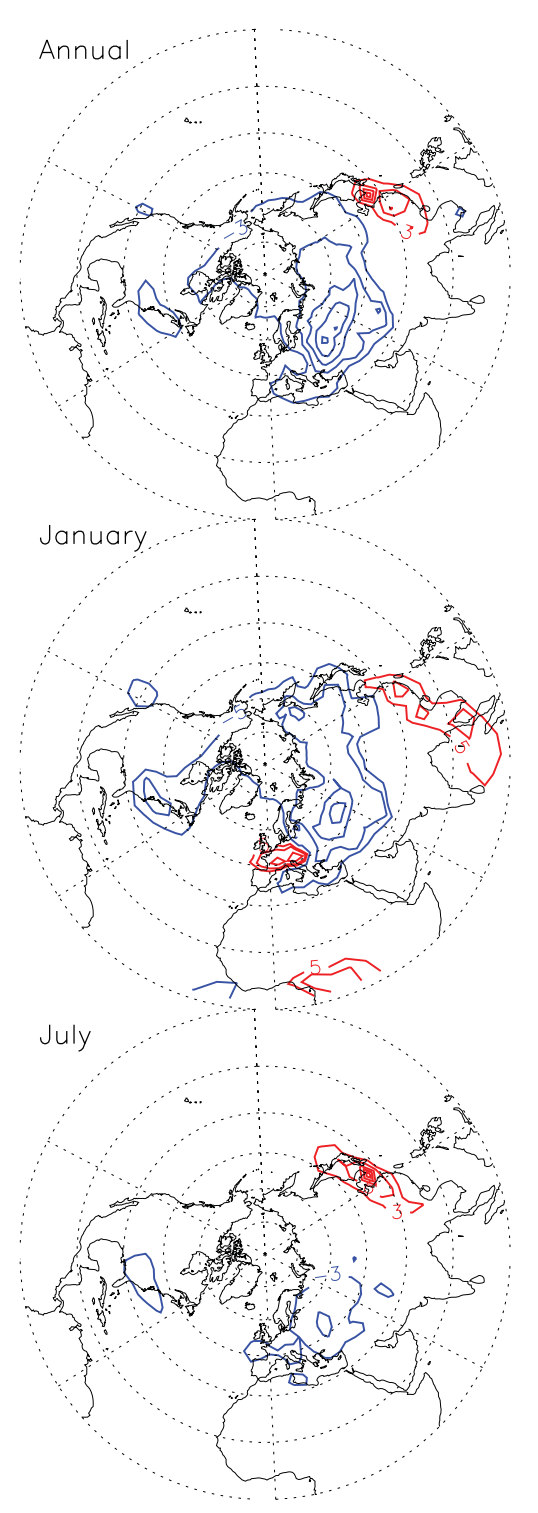

Fig. 3. Trends in surface CO (ppbv/y) for 1988-1997 (top). Downward trends are shown as blue lines, upward trends as red lines, and no trend as green lines with contour spacing of $-21,-18,-15$, $-12,-9,-6,-3,0,3,6,9,12,15,18$, and 21 . January trends (middle) with contour spacing of $-50,-40,-30,-20,-10,-5$, $0,5,10,20,30,40$, and 50 . July trends (bottom) with the same contour spacing as the top panel.

associated with the timing of the burning in the tropics of the $\mathrm{NH}$ and SH. The contribution of biomass burning to the burden in the $\mathrm{HNH}$ reflects transport from the tropics and subtropics, as the extratropical source peaks in summer. The burden from fossil fuels peaks in late boreal winter/early spring in this region, and is similar in magnitude to the burden from biomass burning at that time. The burden from the oxidation of biogenic NMHC is the smallest contributor overall in the $\mathrm{HNH}$, but is $\sim 60 \%$ of the fossil fuel burden in boreal summer.
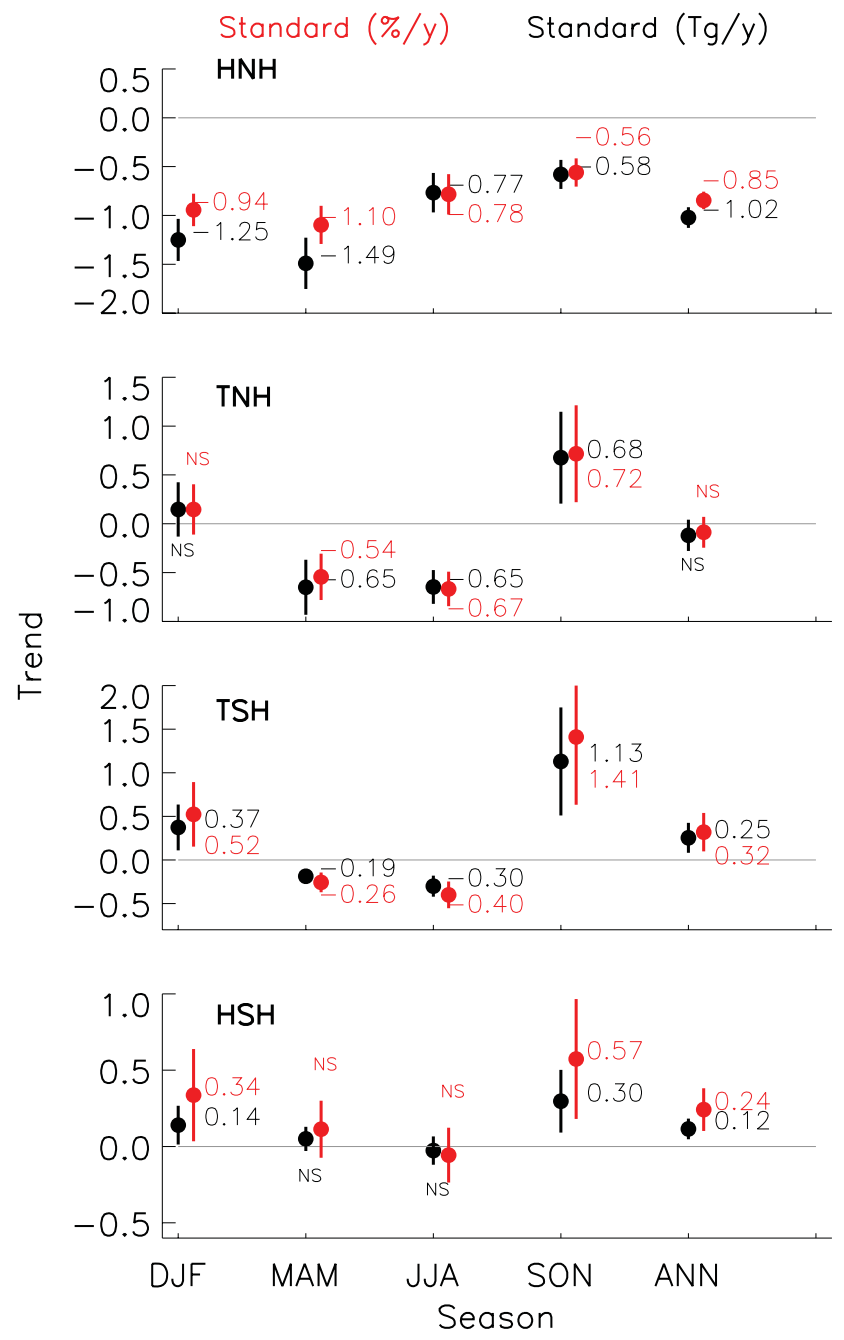

Fig. 4. The seasonal and annual trends for the CO burden $(\% / \mathrm{y}$, $\mathrm{Tg} / \mathrm{y}$ ) in the Standard simulation for 1988-1997; two standard deviations are shown by the vertical lines.

Figure 3 shows the spatial trends in the distribution of the model surface CO (ppbv/y) for 1988-1997 for the NH. (Annual trends were calculated for each surface grid box using monthly means, using $\mathrm{y}=\mathrm{A}+\mathrm{Bx}$ and minimizing the Chisquare error statistic.) There are strong downward annual trends that maximize over Russia ( $<-10 \mathrm{ppbv} / \mathrm{y})$ and strong upward trends in East Asia (2-10 ppbv/y). The annual trends are more heavily weighted to the trends in winter than summer because of wintertime accumulation of $\mathrm{CO}$. There are positive trends in surface CO in January over Western Europe despite the strong decrease in emissions there (Table 1); this trend occurs because the last two winters of our study period were predominately in the negative phase of the NAO as discussed by Duncan and Bey (2004). Over most of the tropics and SH (not shown) there are no significant trends in surface $\mathrm{CO}$ greater than $\pm 1 \mathrm{ppbv} / \mathrm{y}$, except there is an upward trend in Southeast Asia, over the Bay of Bengal, and 

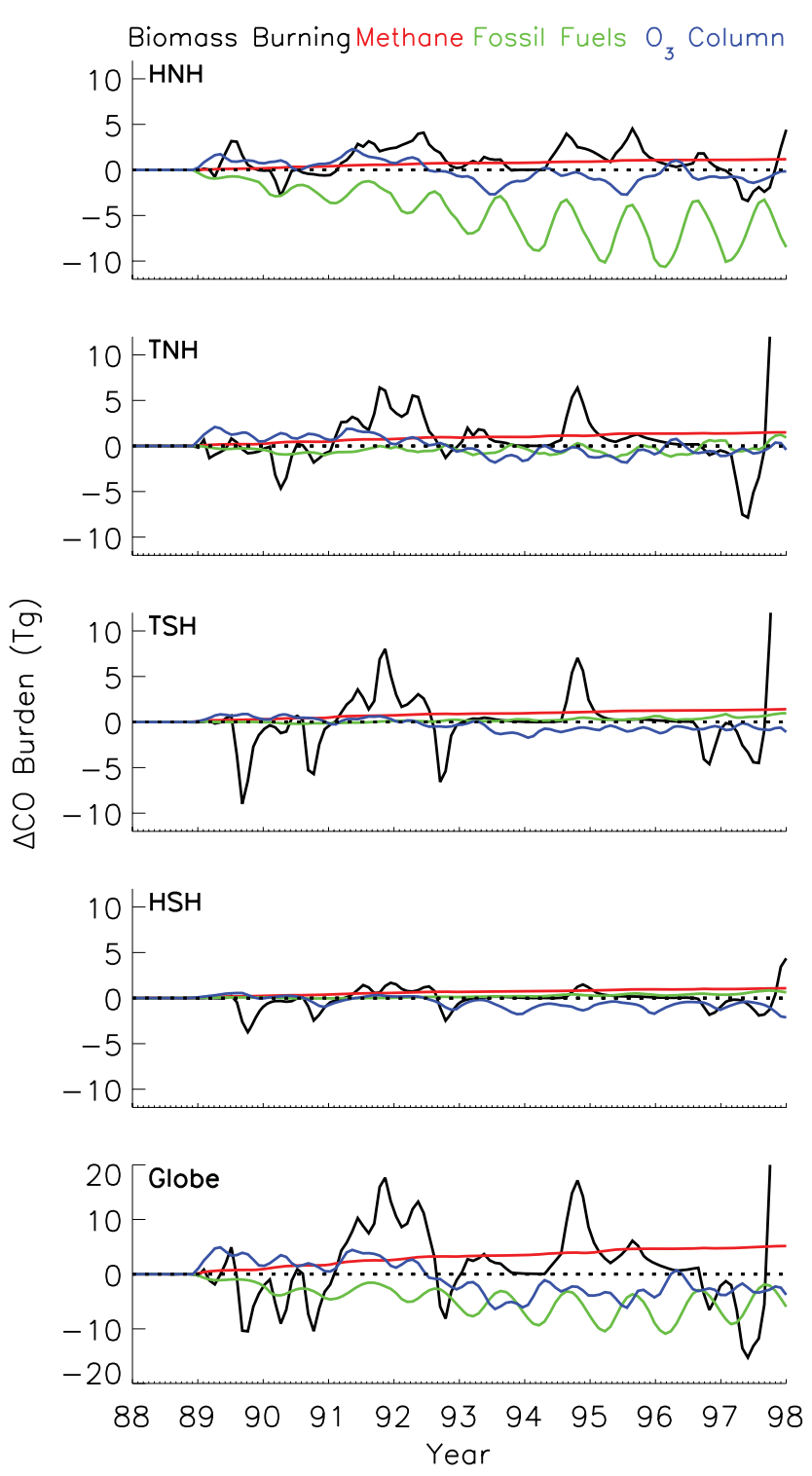

Fig. 5. The deviation of the monthly $\mathrm{CO}$ burden $(\Delta \mathrm{CO} ; \mathrm{Tg})$ for each sensitivity simulation defined as the monthly $\mathrm{CO}$ burden for the Standard simulation minus the monthly burden of the sensitivity simulation.

over northern Africa near the equator. The trends at $500 \mathrm{hPa}$ are mostly not significant (not shown).

Figure 4 shows the trends in the tropospheric $\mathrm{CO}$ burden of the Standard simulation. The seasonal and annual trends in the $\mathrm{HNH}$ are all negative $(-0.5$ to $-1.1 \% / \mathrm{y})$; the largest negative trend occurs in March-May. Overall, the HNH has the largest seasonal and annual trends. The seasonal trends in the tropical bands show considerable variability $(-0.7$ to $1.4 \% / y)$ though the annual trends are not significant in the TNH and are only $0.3 \% / y$ in the TSH. The largest positive trends occur in the tropics in September-November. The smallest trends occur in the HSH.
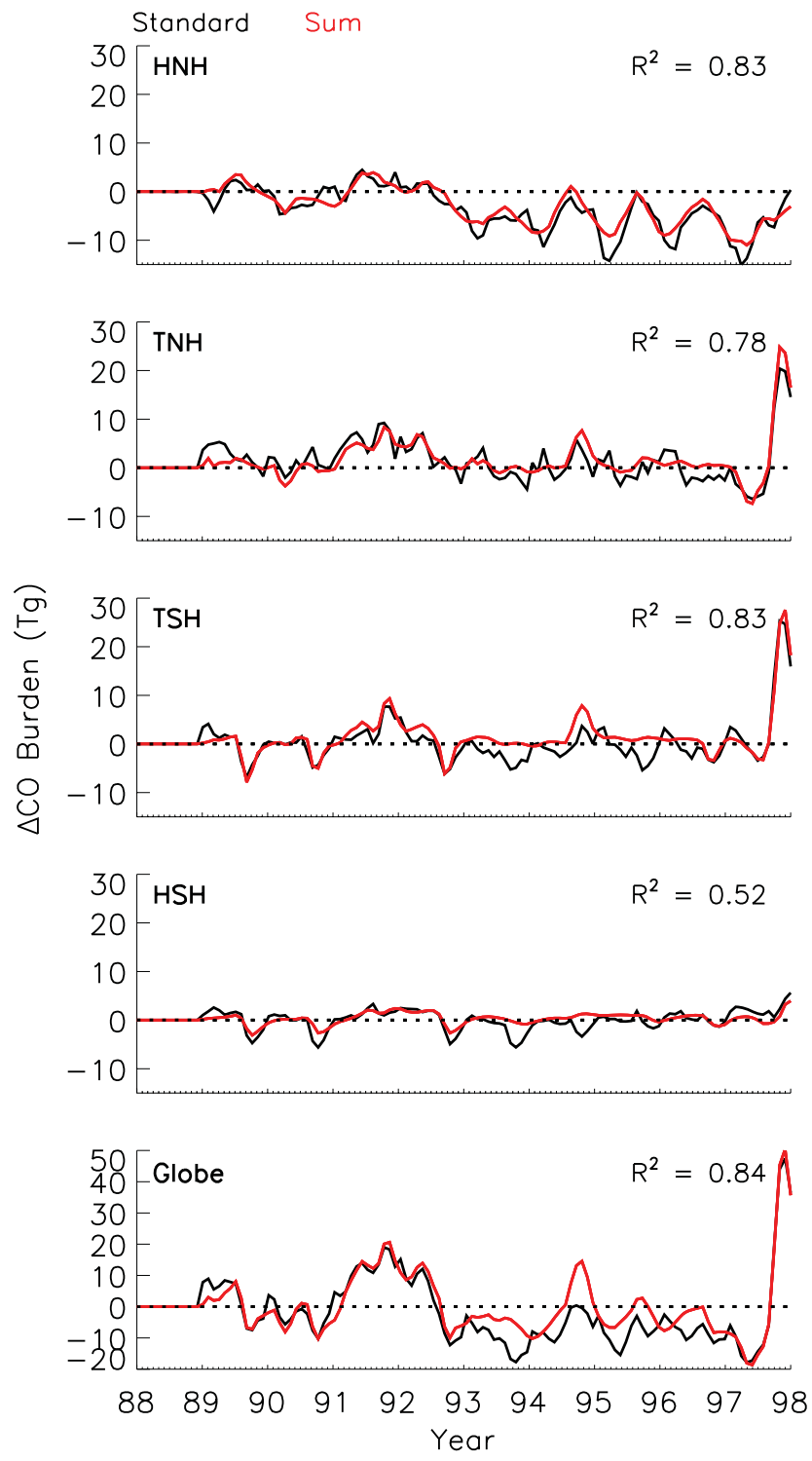

Fig. 6. The same as Fig. 5, except for the Standard simulation (black). The red line represents the sum of the deviations of the four sensitivity simulations in Fig. 5.

\section{Analysis of causes of $\mathrm{CO}$ trends and variability}

Figure 5 shows the effect on the $\mathrm{CO}$ burden of the four main factors influencing trends and IAV: biomass burning, methane, fossil fuels, and the ozone column. For each simulation we fix one of these factors to its values for 1988 for the entire simulation, while allowing the others to vary. The figure shows the monthly deviation of the $\mathrm{CO}$ burden $(\triangle \mathrm{CO})$ in each sensitivity simulation, defined as the monthly burden in the Standard simulation minus the monthly burden in the sensitivity simulation. Interannual variation in biomass burning is the main driver of large-scale, episodic variability in the tropics, especially related to major burning events 


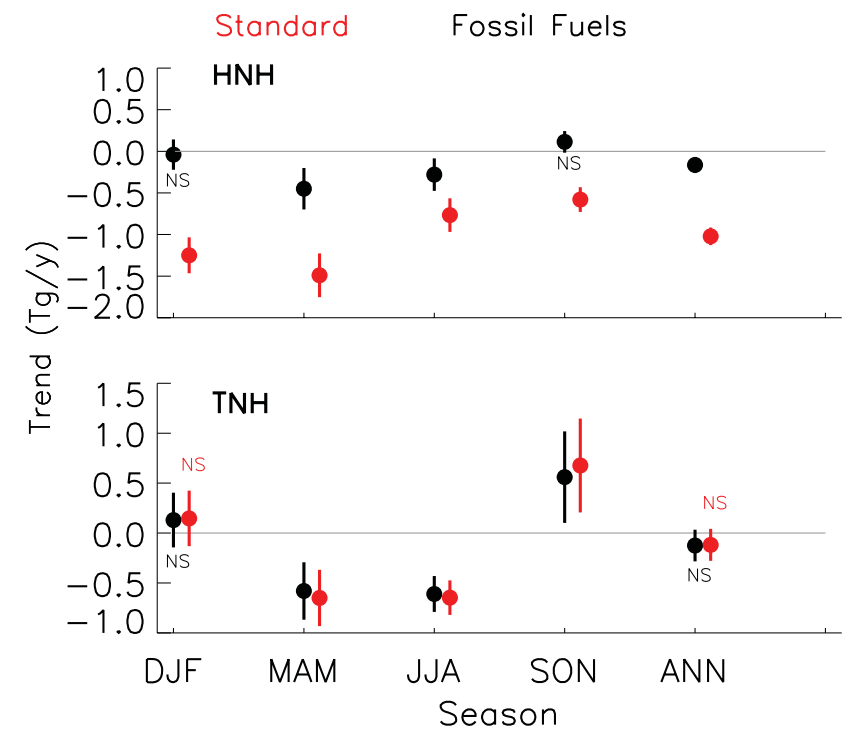

Fig. 7. The seasonal and annual trends for the CO burden (Tg/y) in the standard and fossil fuel sensitivity simulations; two standard deviations are shown by the vertical lines.

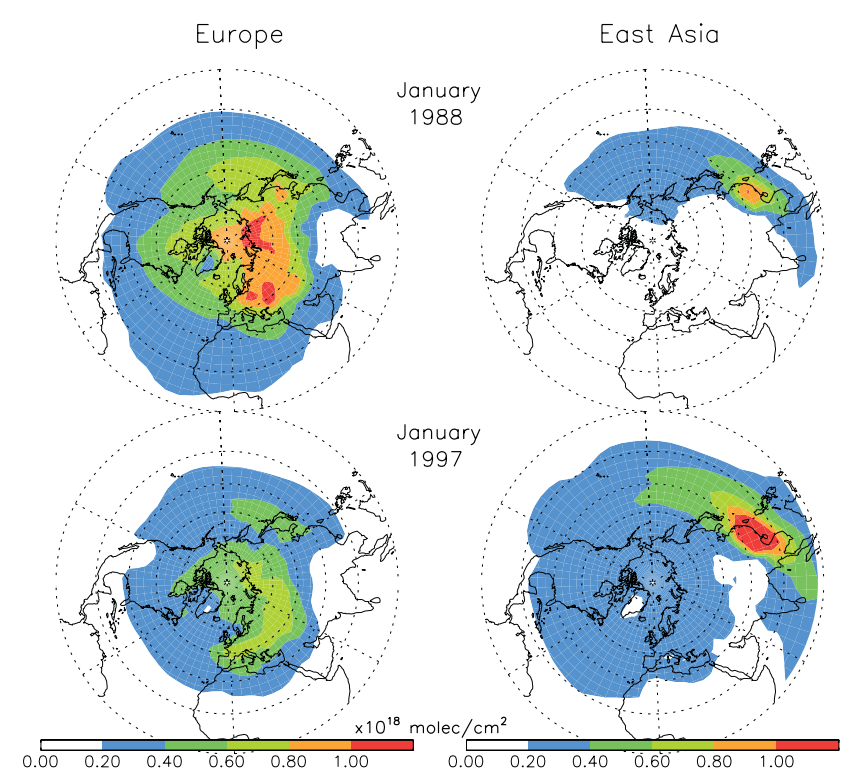

Fig. 8. Total columns of $\mathrm{CO}\left(\times 10^{18} \mathrm{molec} / \mathrm{cm}^{2}\right)$ from fossil fuel emissions from Europe and East Asia in January in 1988 and 1997.

in Indonesia in 1991, 1994, and 1997. In contrast, the upward trend in global methane contributed a monotonic increase in CO. The downward trend in fossil fuels emissions contributed a steady, but seasonally-varying, decrease in the $\mathrm{HNH}$. The changes in the ozone column caused an overall decrease, though with variability.

Figure 6 shows $\triangle \mathrm{CO}$ in the Standard simulation and the sum of $\Delta \mathrm{CO}$ from the four sensitivity simulations in Fig. 5 . There are nonlinear feedbacks between $\mathrm{CO}$, methane, and

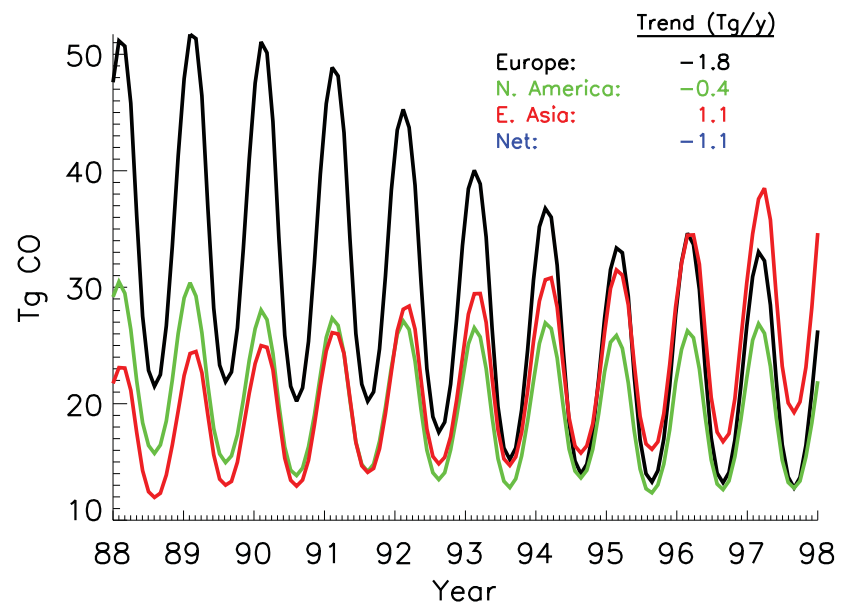

Fig. 9. Monthly tropospheric burden of $\mathrm{CO}(\mathrm{Tg})$ in the $\mathrm{NH}$ from Europe (black), North America (green), and East Asia (red).

$\mathrm{OH}$, so that the components of the total trend caused by the causal factors will not necessarily sum to the total $\mathrm{CO}$ trend in the Standard case. Nevertheless, the figure shows that these four causal factors explain the majority of $\mathrm{CO}$ variability globally $\left(R^{2}=0.84\right)$ for $1988-1997$ and in the $\mathrm{HNH}$, TNH, and TSH $(0.78-0.83)$. However, only about half is explained in the HSH $\left(R^{2}=0.52\right)$. Our sensitivity simulation where we fix the transport for each year to that in 1988 shows that transport explains much of the remaining variability in the HSH. This result is not surprising for the $\mathrm{HSH}$ as most of the CO there is imported from the tropics.

\subsection{Impact of regional trends in Fossil fuel emissions}

The net change in NH fossil emissions is small (Table 1), although there are large regional changes in emissions and in trends in surface CO (Fig. 3). Figure 7 shows the trends in the $\mathrm{CO}$ burden for the Standard run and for the simulation with fossil fuel emissions fixed to 1988 levels. The negative trends in the Standard simulation in the HNH become insignificant or less negative in the sensitivity run. However, the trends in the TNH are similar for both simulations. The decrease in European emissions is the primary cause of the decrease in the $\mathrm{CO}$ burden at higher latitudes, but the effect of the decrease in $\mathrm{CO}$ from Europe on $\mathrm{CO}$ at lower latitudes is offset by the increase in $\mathrm{CO}$ from Asia as illustrated in Fig. 8, which shows the total columns of $\mathrm{CO}$ from Asian and European sources in January of 1988 and 1997.

The $\mathrm{CO}$ burden in the $\mathrm{NH}$, especially in the $\mathrm{HNH}$, is more influenced by the decrease in European emissions than by the similar increase in Asian emissions for two reasons (Fig. 9). First, pollution from Europe is emitted at higher latitudes $\left(40^{\circ}-65^{\circ} \mathrm{N}\right)$ than that from North America $\left(30^{\circ}-45^{\circ} \mathrm{N}\right)$ and from East Asia $\left(20^{\circ}-40^{\circ} \mathrm{N}\right.$, but mainly $\left.30^{\circ}-40^{\circ} \mathrm{N}\right)$. The average lifetime of $\mathrm{CO}$ increases with latitude, particularly in winter when $\mathrm{CO}$ behaves like an inert tracer at high latitudes. 

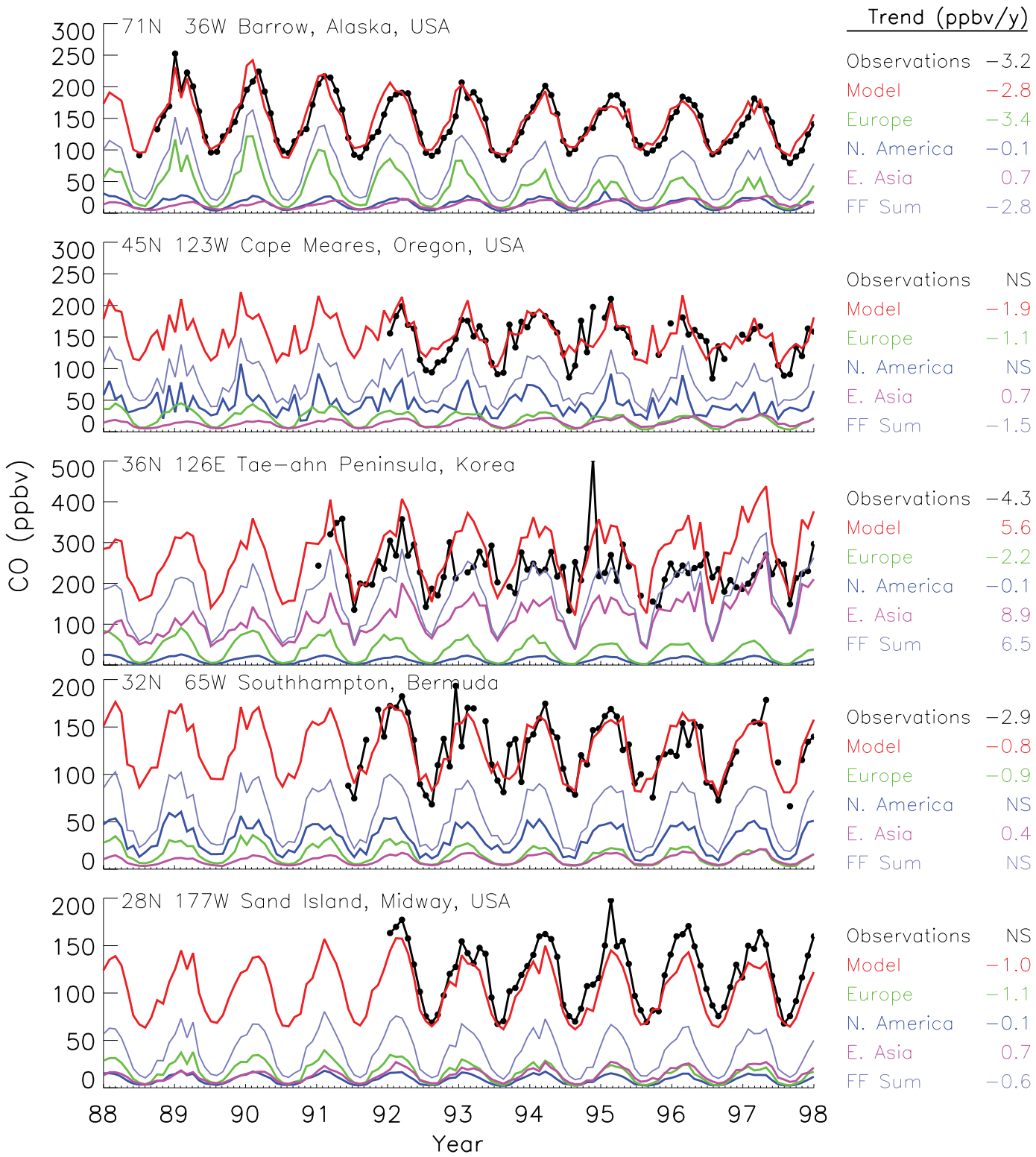

Fig. 10. Surface CO (black line with dots) observed at several NOAA/GMD stations. The red line represents total model CO in the Standard run. CO from fossil fuel emissions from Europe, East Asia, and North America are shown as green, magenta, and blue lines, respectively. The sum of all three fossil fuel tracers is shown in pale blue.

Second, in winter, much of the export of pollution from Europe occurs near the surface towards Russia and the Arctic (Duncan and Bey, 2004), while some CO from East Asia is transported to the southwest over Indochina and the Bay of Bengal (Newell and Evans, 2000; Bey et al., 2001b; Stohl et al., 2002; Liu et al., 2003) into a region where its lifetime is less than a month. These transport pathways are evident in Fig. 8. The annual emissions of $\mathrm{CO}$ from Europe and Asia are similar in 1992 (Table 1), but the greater hemispheric burden of European CO is clear (Fig. 9). As a result, the decrease in the $\mathrm{CO}$ burden from European sources $(-1.8 \mathrm{Tg} / \mathrm{y})$ is larger in magnitude than the increase in the burden from Asian sources (+1.1 Tg/y) as shown in Fig. 9.
We used tagged tracer simulations to examine the contributions of regional trends in fossil fuel emissions at GMD stations that are downwind of major source regions (Fig. 10). The decrease in model $\mathrm{CO}$ at Barrow, Alaska ( $-2.8 \mathrm{ppbv} / \mathrm{y})$, is mostly due to $\mathrm{CO}$ from European fossil fuel emissions $(-3.4 \mathrm{ppbv} / \mathrm{y})$, and agrees well with the observed trend (-3.2 ppbv/y). The burdens from East Asian and North American sources are much smaller than that from Europe in 1988 , but by 1997 all three are of more similar magnitude. The model captures the seasonality of the trend, largest in winter and spring, with the greatest effect of European sources during these seasons (Fig. 11). European pollution plays less of a role in determining the overall trend at 


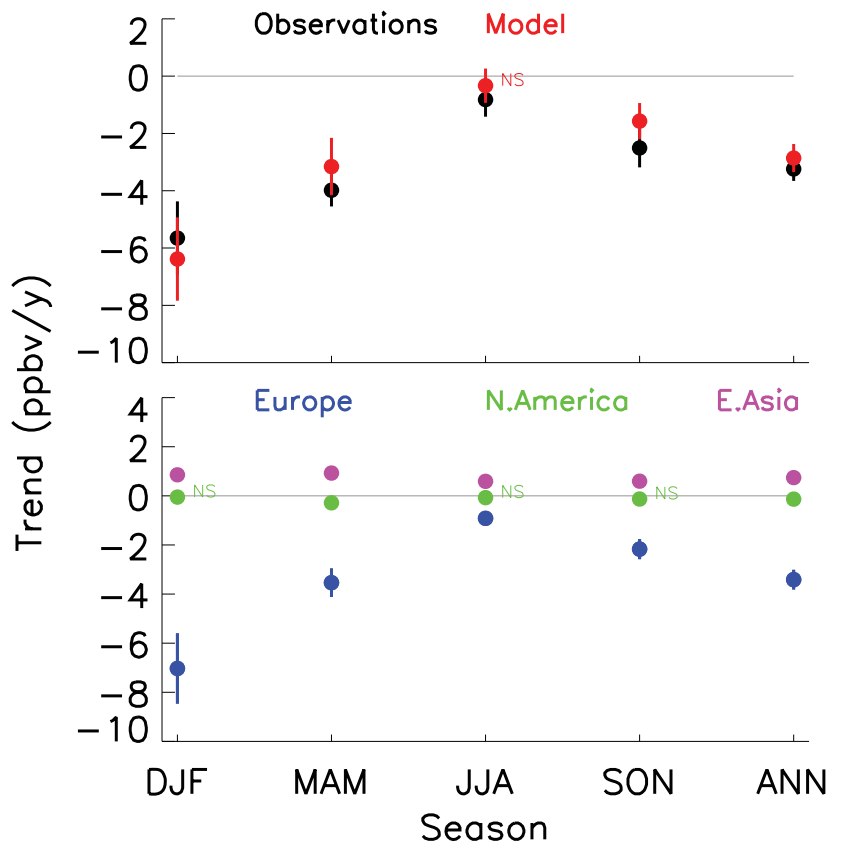

Fig. 11. (top) Trends (ppbv/y) for the model and observed $\mathrm{CO}$ at the NOAA/GMD station in Barrow, Alaska. (bottom) Trends for tagged tracers from three industrialized regions; two standard deviations are shown by the vertical lines.

lower latitudes, but the decrease in European $\mathrm{CO}$ is evident, including at Tae-ahn, Korea $(-2.2 \mathrm{ppbv} / \mathrm{y})$, Cape Meares $(-1.1 \mathrm{ppbv} / \mathrm{y})$, and Midway ( $-1.1 \mathrm{ppbv} / \mathrm{y})$ in Fig. 10. The effect of the decrease in European sources for 1988-1997 is offset by the increase in East Asian fossil fuel emissions at most of the midlatitude sites (e.g., Bermuda, Midway). Slightly negative or insignificant trends in $\mathrm{CO}$ from North American sources occur at the stations, even at Bermuda which is typically impacted by the outflow of North America, reflecting the relatively weaker decrease in emissions (Table 1).

\subsection{Methane and overhead ozone columns}

The trends in the simulation where the overhead ozone columns were fixed to 1988 levels are less negative than those in the Standard simulation, as shown in Fig. 12. The observed decrease in the ozone columns for 1988-1997 contributed a negative component to the CO trend in the Standard case by enhancing $\mathrm{CO}$ loss through reaction with $\mathrm{OH}$. On the other hand, the observed increase in methane contributed a positive component as it led to an increase in the source of CO from methane oxidation (Fig. 12).

The compensating nature of the observed trends in column ozone and methane on CO trends (Fig. 5) is fortuitous for our study period. The trends in the ozone column depend, in part, on the solar cycle, leading to an increase in OH in 1988-1997, but the 11-y solar cycle should contribute
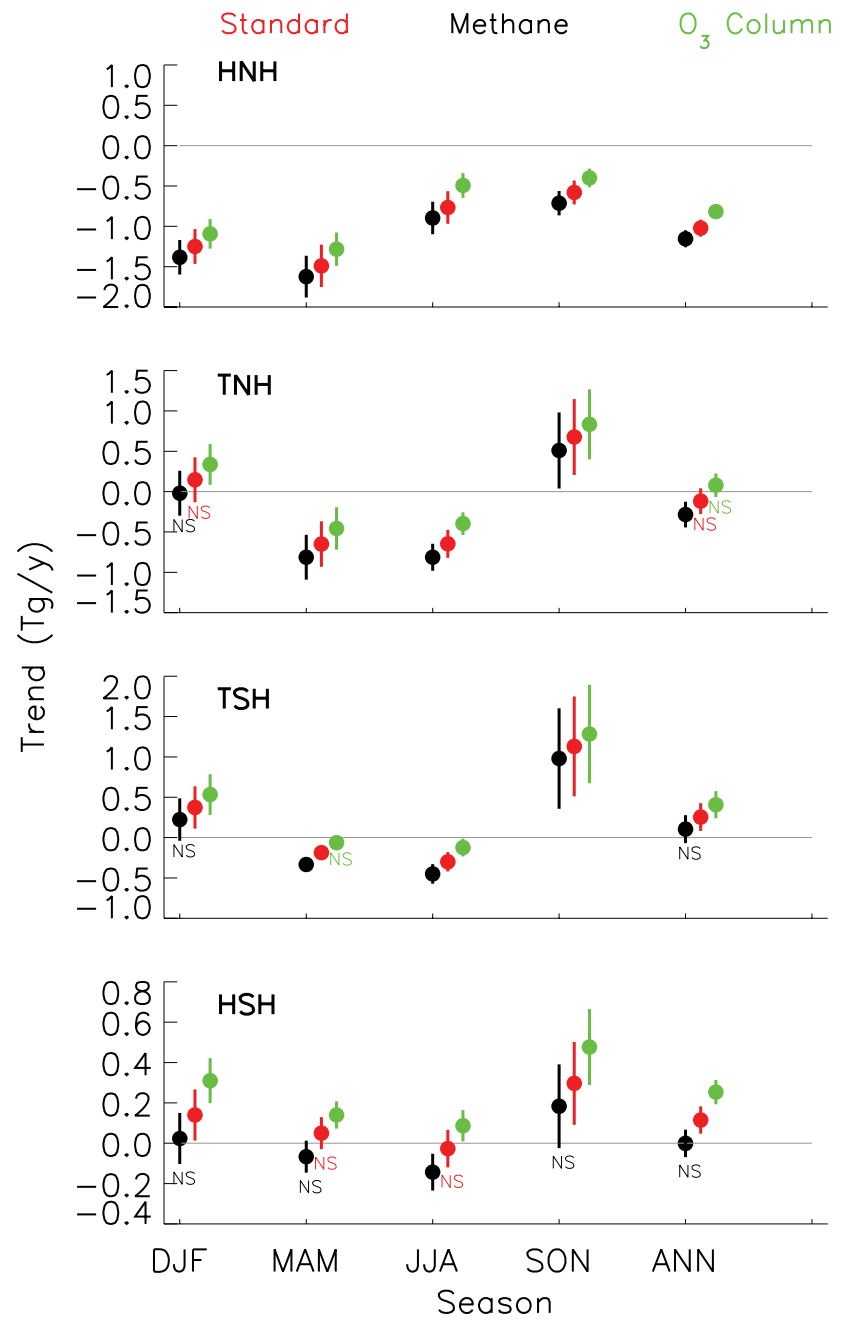

Fig. 12. The seasonal and annual trends for the CO burden (Tg/y) for the standard and two sensitivity simulations; two standard deviations are shown by the vertical lines.

a regular cyclic component to the trend in $\mathrm{OH}$ and hence in CO. Consequently, the trend in methane (should it increase again) and the cycle in the overhead ozone column may alternate from canceling each other to reinforcing each other in their effects on $\mathrm{CO}$ trends.

The observed trends in column ozone and methane did not have a compensating effect on $\mathrm{OH}$ (Fig. 13). Clearly, model $\mathrm{OH}$ is sensitive to changes in the overhead ozone column in the tropics year-round $( \pm 4 \%)$ and in the middle and high latitudes in local summer $( \pm 5 \%)$. In the $\mathrm{HNH}$ and $\mathrm{HSH}$, there is significant IAV in $\mathrm{OH}$ which will prejudice any trend; two deviations in $\mathrm{OH}$ in the $\mathrm{HNH}$ in 1993 and 1995 are associated with strong negative deviations in the overhead ozone column (Fig. 1). In contrast, the trend in methane has little impact on $\mathrm{OH}$ (Fig. 13) as reaction with methane is not the primary sink for $\mathrm{OH}$. 


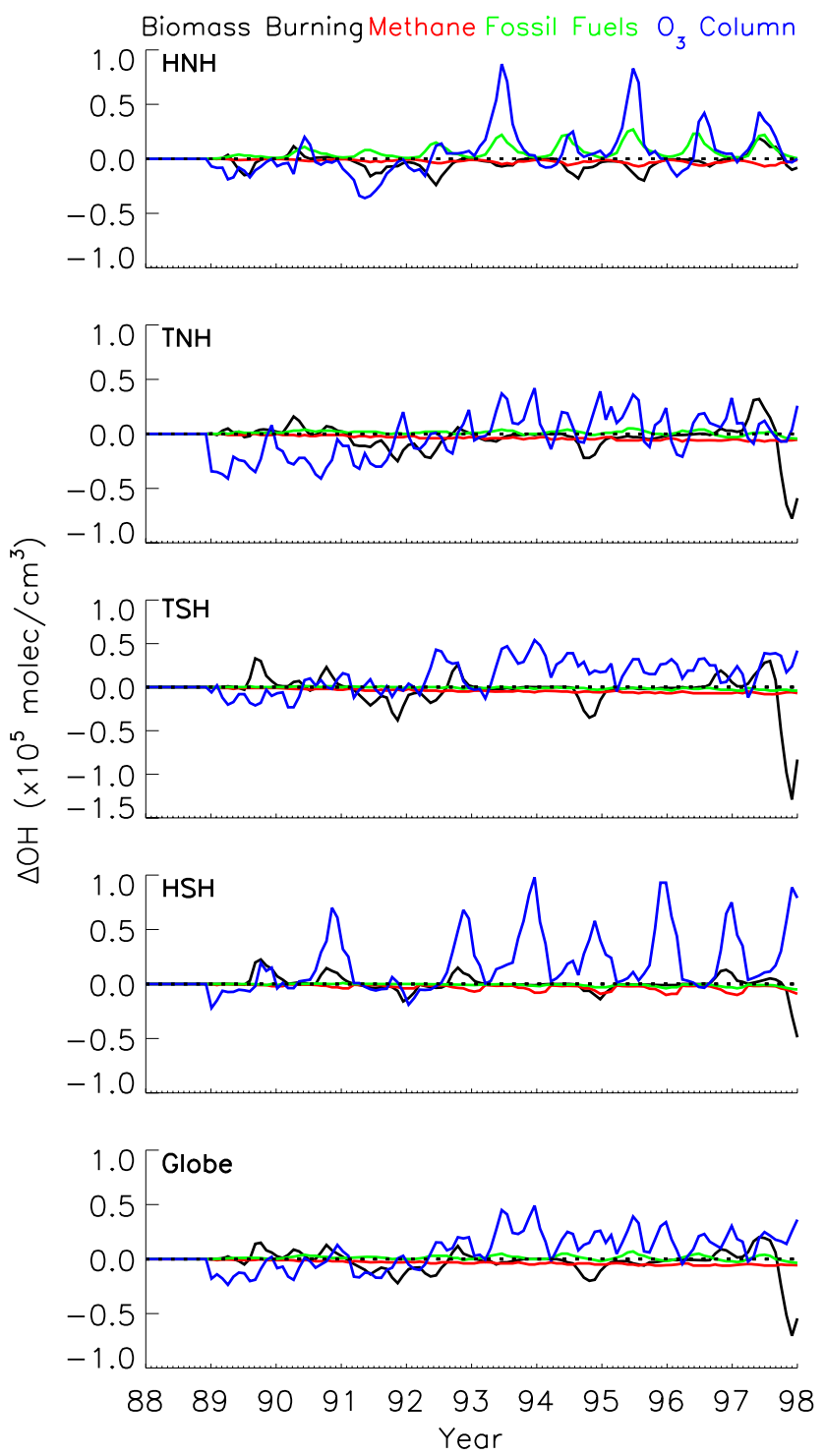

Fig. 13. Same as Fig. 5, except for tropospheric mean $\mathrm{OH}$.

The trends in $\mathrm{OH}$ in the Standard run are positive in the tropical bands in all seasons for 1988-1995, but are not significant for 1988-1997 for the TSH and for SeptemberFebruary in the TNH (Fig. 4). As will be discussed in Sect. 5.5, the component of the upward trend in $\mathrm{OH}$ from the decreasing ozone columns is partially offset by the loss of $\mathrm{OH}$ through reaction with $\mathrm{CO}$ from the Indonesian fires.

\subsection{Episodic high-impact events}

Trends are particularly sensitive to extreme events near the start or end of the time series being considered. Novelli et al. (2003) estimated that the global trend in surface CO for 1991-2001 ( $-0.52 \mathrm{ppbv} / \mathrm{y})$ would be $-1.5 \mathrm{ppbv} / \mathrm{y}$ if data from mid-1997 to mid-1999 were removed from the calculation; abnormally large emissions of CO occurred in 1997 and
$1988-1995 \quad 1988-1997$
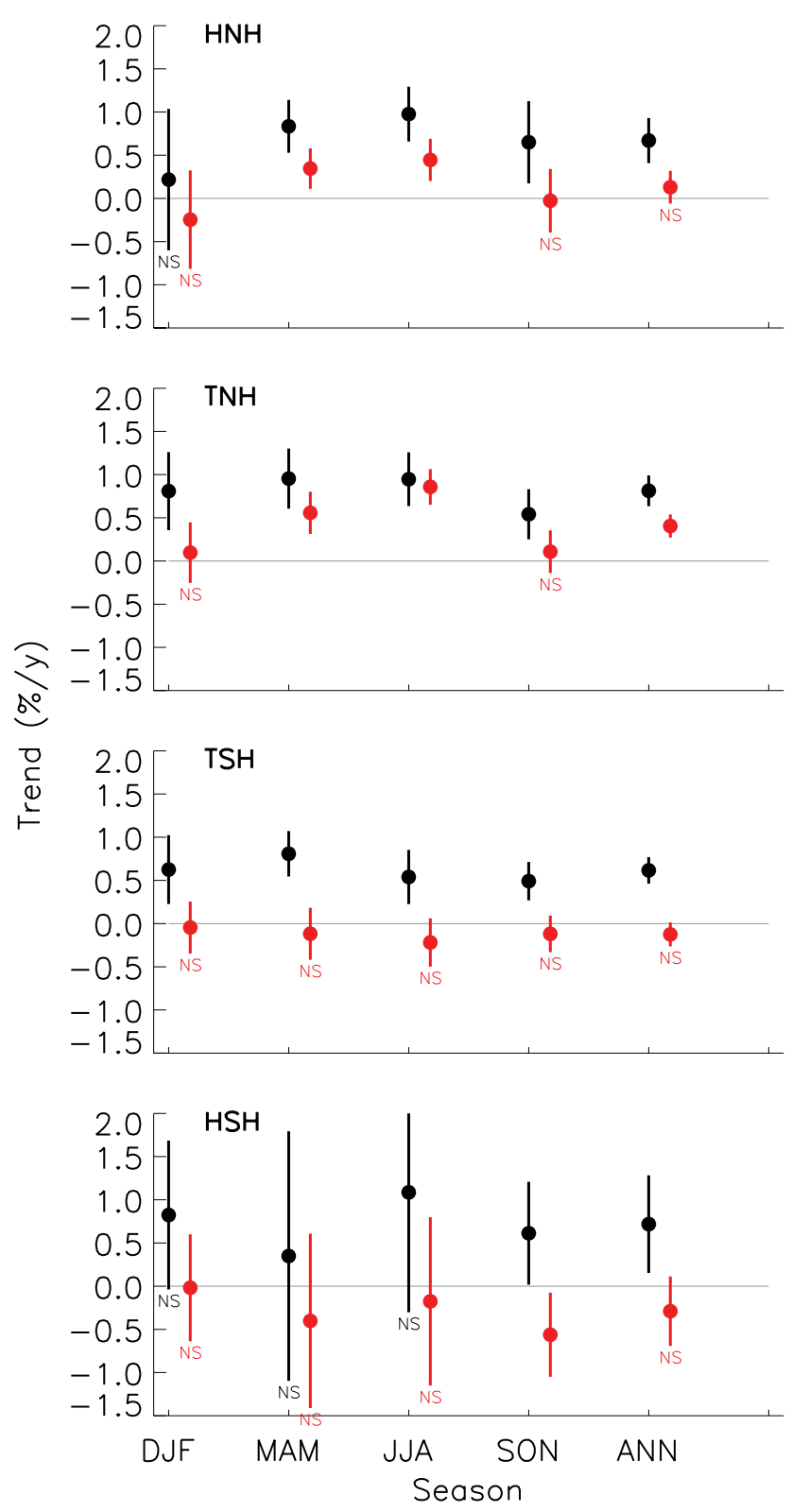

Fig. 14. Trends $(\% / y)$ for model $\mathrm{OH}$ in the Standard simulation; two standard deviations are shown by the vertical lines.

1998 from wildfires in Indonesia (late 1997, early 1998), the boreal forests (in 1998), and Mexico (in 1998), perturbing the tropospheric CO burden by $16 \%$ on average for almost 3 years.

It is apparent from Fig. 5 that including or excluding 1997 in our analysis will impact the calculated trends, especially in the tropics. Figure 15 shows the seasonal and annual trends in the Standard simulation and the sensitivity simulation with the biomass burning emissions fixed to 1988 levels. The seasonal trends are similar in both runs for all seasons, 


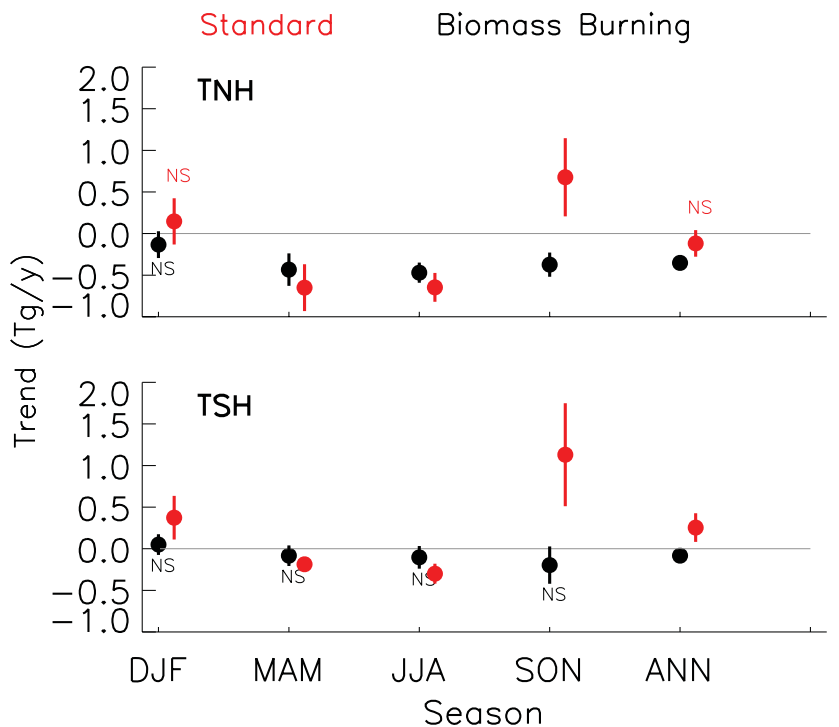

Fig. 15. The seasonal and annual trends for the CO burden (Tg/y) in the standard and biomass burning sensitivity simulations; two standard deviations are shown by the vertical lines.

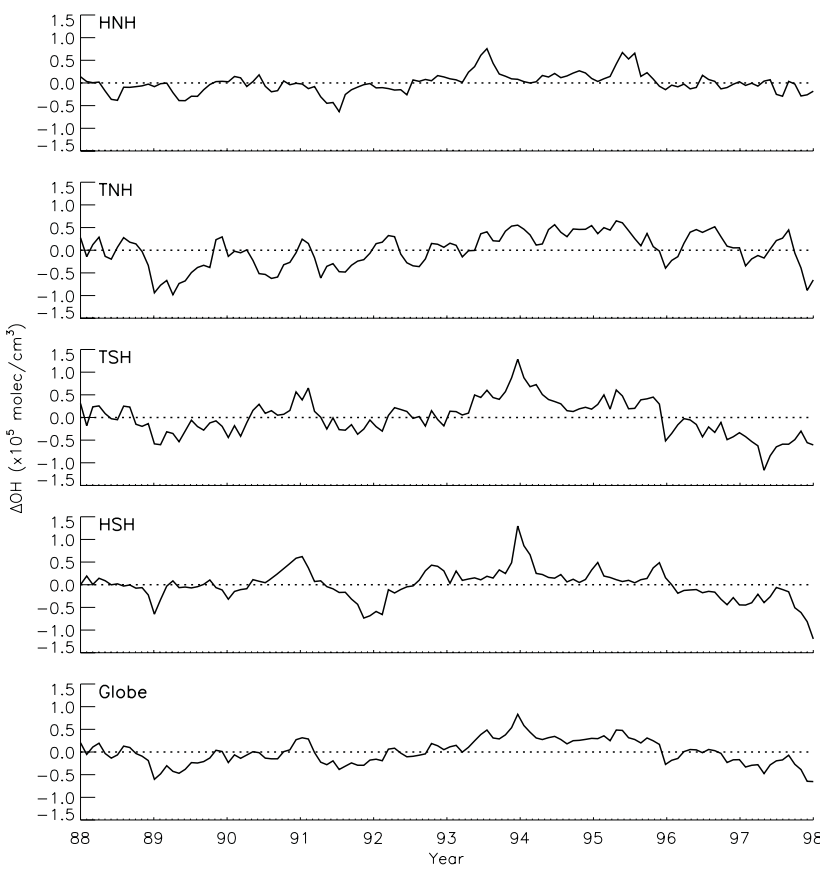

Fig. 16. Tropospheric mean, monthly $\mathrm{OH}$ with the mean for 1988 1997 removed.

except September-November when the Indonesia fires occurred. The positive trends in the TNH and TSH in the Standard run are negative or not significant in the sensitivity simulation.

There is not a major response of the model CO burden to the aftermath of the Mt. Pinatubo eruption in June 1991 (Fig. 5). Fuglestvedt et al. (1994) found the response of methane was damped as the largest changes in the column occurred outside of the tropics and in winter (Fig. 1). Model calculations in the literature indicate that $\mathrm{OH}$ initially decreased during the first year following the eruption because of the scattering effects of sulfate aerosols, which reduced the amount of UV radiation in the troposphere (Dlugokencky et al., 1996), and began to increase in 1992 and 1993 as the ozone column decreased in 1992/1993 (Fig. 1; Bekki et al., 1994). We do not include the scattering effects of stratospheric sulfate aerosols on photolysis rates. Dlugokencky et al. (1996) estimated that tropical OH decreased by about $10 \%$ because of the stratospheric aerosols which would cause $\mathrm{CO}$ to increase by about $8 \mathrm{ppbv}$. This estimated increase would cause a minor change in the trend in tropical CO (Fig. 5) in our model, which would not affect any of our conclusions.

\subsection{Transport}

The sensitivity simulation, where we fix transport fields throughout the simulation to those of 1988, does not provide useful information on the causes of CO trends as 1988 began in a weak El Niño and ended in a strong La Niña. Thus the natural transition between the ENSO phases is broken by repeating 1988 meteorology, possibly introducing a spurious forcing to this sensitivity simulation.

\subsection{Contributions of causal factors to trends in Model $\mathrm{OH}$}

The hydroxyl radical is sensitive to a number of factors (e.g., Spivakovsky et al, 2000), especially to changes in the ozone column (see Fig. 13) and to changes in CO itself, as about $60 \%$ of the sink of $\mathrm{OH}$ is through reaction with $\mathrm{CO}$. Global mean $\mathrm{OH}$ in our simulation is $\sim 0.9 \times 10^{6} \mathrm{molec} / \mathrm{cm}^{3}$ (Duncan et al., 2007). Figure 16 shows the monthly-average $\mathrm{OH}$ with the monthly mean (1988-1997) removed. Globally, model $\mathrm{OH}$ varies $\pm 10 \%$ about the mean for 1988-1997. Interannual variability in $\mathrm{OH}$ of this magnitude was derived also from analysis of data for methyl chloroform for different time periods (Bousquet et al., 2005; Prinn et al., 2005).

Figure 14 shows that the seasonal $\mathrm{OH}$ trends in the Standard run for 1988-1997 in all four zonal bands are not significant, except in NH spring and summer $(<0.5 \% / \mathrm{y})$ and the HSH in September-November $(-0.5 \% / y)$. The component of the trend in $\mathrm{OH}$ associated with trends in the ozone column is important in the tropics year-round and in the high latitudes in local spring and summer, as shown in Fig. 13. The component of the $\mathrm{OH}$ trend in the tropics due to biomass burning is approximately counter-balanced by that due to the overhead ozone column in September-November. Biomass burning caused decreases in $\mathrm{OH}$ as high as $10 \%$ during the 1997 Indonesian fires in the tropics. The influence of fossil fuels is comparatively weak, except in the $\mathrm{HNH}$; the decrease in $\mathrm{CO}$ from fossil fuels impacts $\mathrm{OH}$ predominately in spring, when $\mathrm{CO}$ is seasonally high, and early summer 
( $\pm 2 \%$; Fig. 13), when $\mathrm{OH}$ is seasonally high. The impact of the trend in methane is small as noted above.

\section{Summary}

We presented a comprehensive analysis of the causes of the trends and interannual variability of tropospheric $\mathrm{CO}$ for 1988-1997. The northern extra-tropics experienced a downward trend in the $\mathrm{CO}$ burden in all seasons, highest in winter $(-1.3 \mathrm{Tg} / \mathrm{y})$ and spring $(-1.5 \mathrm{Tg} / \mathrm{y})$, associated with the downward trend in fossil fuel emissions from Europe. The higher latitudes responded strongly to the decrease in European sources, but not to the similar increase in Asian sources, as the former are emitted further north and transport pathways favor accumulation at higher latitudes in winter and spring. However, the opposite trends in the $\mathrm{CO}$ burdens from these two source regions counterbalanced at lower latitudes.

A monotonic increase in methane between 1988 and 1997 contributed positively to $\mathrm{CO}$, but the concurrent decrease in the ozone column and concomitant increase in $\mathrm{OH}$ caused a compensating decrease in $\mathrm{CO}$. Consequently, the annual trends in $\mathrm{CO}$ in the tropics and southern extra-tropics were small $(0.25 \mathrm{Tg} / \mathrm{y})$ or insignificant. The decrease in the ozone column in the tropics resulted from our study period beginning near a maximum in the solar cycle and ending near a minimum, and the solar cycle causes an 11 year cycle in $\mathrm{OH}$ on longer time scales. Should methane increase in the future, components of the $\mathrm{CO}$ trend from methane oxidation and the ozone column may alternate between canceling and reinforcing one another.

Two large events occurred during our study period, but only one impacted $\mathrm{CO}$ trends significantly. The Indonesian wildfires in late 1997 released a tremendous amount of CO over about 3 months. Consequently, the trends in tropical $\mathrm{CO}$ were high $(0.7-1.1 \mathrm{Tg} / \mathrm{y})$ in September-November. The trend in the southern extra-tropics $(0.6 \mathrm{Tg} / \mathrm{y})$ was also affected by transport of $\mathrm{CO}$ from this event. Although large fires also occurred in Indonesia in 1991 and 1994, they had far less impact on trends, but they impacted IAV of $\mathrm{CO}$ considerably. The second large event, the eruption of Mt. Pinatubo had a relatively small impact on $\mathrm{OH}$, and subsequently $\mathrm{CO}$, as it occurred during the middle of our study period and the largest decreases in the ozone columns occurred at high latitudes in winter when $\mathrm{OH}$ is seasonally low.

The increases in model $\mathrm{OH}$ were significant in spring and summer in the northern extra-tropics, and were associated with the decrease in the ozone column and in European CO sources. In the southern extra-tropics, the $\mathrm{OH}$ trends were primarily influenced by the decrease in the ozone columns. The trends in OH for $1988-1995$ were positive in all regions, but the 1997 Indonesian wildfires strongly influenced the tropical trends for 1988-1997, effectively negating the impact of decreasing ozone columns. The trends in model $\mathrm{OH}$ were weak or not significant and there was large variabil- ity, $\pm 10 \%$ about the mean, for $1988-1997$. These findings are in general agreement with other studies, which inferred trends in $\mathrm{OH}$ from observations of methyl chloroform and ${ }^{14} \mathrm{CO}$ (Bousquet et al., 2005; Manning et al., 2005; Prinn et al., 2005).

Acknowledgements. B. Duncan gratefully acknowledges important discussions with Stacey Frith on trends in column ozone and thanks Jerry Ziemke for guidance on the calculation of trends. This research was supported by NASA Grant NAG-1-2307 (B. Duncan) and by the National Science Foundation grant ATM-0554804 to Harvard University (J. Logan).

Edited by: P. Monks

\section{References}

Allan, R. J. and D'Arrigo, R. D.: Persistent ENSO sequences: How unusual was the 1990-1995 El Niño?, Holocene, 9(1), 101-118, 1999.

Altshuller, P.: The production of carbon monoxide by the homogeneous $\mathrm{NO}_{\mathrm{x}}$-induced photooxidation of volatile organic compounds in the troposphere, J. Atmos. Chem., 13, 155-182, 1991.

Bekki, S., Law, K. S., and Pyle, J. A.: Effect of ozone depletion on atmospheric methane and CO concentrations, Nature, 371, 595597, 1994.

Bell, G. D. and Halpert, M. S.: Climate Assessment for 1997, B. Am. Meteorol. Soc., 79, S1-S50, 1998.

Bey, I., Jacob, D. J., Yantosca, R. M., et al.: Global modeling of tropospheric chemistry with assimilated meteorology: Model description and evaluation, J. Geophys. Res., 106(D19), $23073-$ 23 095, 2001a.

Bey, I., Jacob, D. J., Logan, J. A., and Yantosca, R. M.: Asian chemical outflow to the Pacific: Origins, pathways and budgets, J. Geophys. Res., 106(D19), 23 097-23 113, 2001 b.

Bousquet, P., Hauglustaine, D. A., Peylin, P., Carouge, C., and Ciais, P.: Two decades of $\mathrm{OH}$ variability as inferred by an inversion of atmospheric transport and chemistry of methyl chloroform, Atmos. Chem. Phys., 5, 2635-2656, 2005, http://www.atmos-chem-phys.net/5/2635/2005/.

Brunke, E.-G., Scheel, H. E., and Seiler, W.: Trends of tropospheric $\mathrm{CO}, \mathrm{N}_{2} \mathrm{O}$ and methane as observed at Cape Point, South Africa, Atmos. Environ., 24A, 585-595, 1990.

Dlugokencky, E. J., Dutton, E. G., Novelli, P. C., Tans, P. P., Masarie, K. A., Lantz, K. O., and Madronich, S.: Changes in methane and $\mathrm{CO}$ growth rates after the eruption of Mt. Pinatubo and their link with changes in tropical tropospheric UV flux, Geophys. Res. Lett., 23, 2761-2764, 1996.

Dlugokencky, E. J., Masarie, K. A., Lang, P. M., and Tans, P. P.: Continuing decline in the growth rate of atmospheric methane burden, Nature, 393, 447-450, 1998.

Duncan, B. N., Portman, D., Bey, I., and Spivakovsky, C. M.: Parameterization of $\mathrm{OH}$ for efficient computation in chemical tracer models, J. Geophys. Res., 105(D10), 12 259-12 262, 2000.

Duncan, B. N., Martin, R. V., Staudt, A. C., Yevich, R. M., and Logan, J. A.: Interannual and Seasonal Variability of Biomass Burning Emissions Constrained by Satellite Observations, J. Geophys. Res., 108(D2), 4040, doi:10.1029/2002JD002378, 2003a. 
Duncan, B. N., Bey, I., Chin, M., Mickley, L. J., Fairlie, T. D., Martin, R. V., and Matsueda, H.: Indonesian Wildfires of 1997: Impact on Tropospheric Chemistry, J. Geophys. Res., 108(D15), 4458, doi:10.1029/2002JD003195, 2003b.

Duncan, B. N. and Bey, I.: A Modeling Study of the Export Pathways of Pollution from Europe: Seasonal and Interannual Variations (1987-1997), J. Geophys. Res., 109, D08301, doi:10.1029/2003JD004079, 2004.

Duncan, B. N., Logan, J. A., Bey, I., Megretskaia, I. A., Yantosca, R. M., Novelli, P. C., Jones, N. B., and Rinsland, C. P.: Global budget of CO, 1988-1997: Source estimates and validation with a global model, J. Geophys. Res., 112(D22), D22301, doi:10.1029/2007JD008459, 2007.

Fuglestvedt, J. S., Jonson, J. E., and Isaksen, I. S. A.: Effects in reductions in stratospheric ozone on tropospheric chemistry through changes in photolysis rates, Tellus, 46B, 172-192, 1994.

Glantz, M. H.: Currents of Change, Impacts of El Niño and La Niña on Climate and Society, 84-100, Cambridge Univ. Press, New York, 2001.

Holloway, T., Levy II, H., and Kasibhatla, P.: Global distribution of carbon monoxide, J. Geophys. Res., 105(D10), 12 123-12 147, 2000.

Hurrell, J. W. and Folland, C. K.: A change in the summer atmospheric circulation over the North Atlantic, in Exchanges: Selected Research Papers, 7, Clim. Variability and Predict., World Clim. Res. Progr., Southampton, UK, 2002.

Khalil, M. A. K. and Rasmussen, R. A.: Carbon monoxide in the Earth's atmosphere: Indications of a global increase, Nature, 332, 242-245, 1988

Khalil, M. A. K. and Rasmussen, R. A.: Global decrease in atmospheric carbon monoxide concentration, Nature, 370, 639-641, 1994.

Lau, K.-M. and Yang, S.: Walker circulation, in: Encyclopedia of Atmospheric Sciences, edited by: Holton, J., Pyle, J. P., and Curry, J., 2505-2509, Academic, San Diego, Calif., 2002.

Liu, H., Jacob, D. J., Bey, I., Yantosca, R. M., and Duncan, B. N.: Transport pathways for Asian pollution outflow over the Pacific: Interannual and seasonal variations, J. Geophys. Res., 108(D20), 8786, doi:10.1029/2002JD003102, 2003.

Lobert, J., Keen, W., Logan, J., and Yevich, R.: Global chlorine emissions from biomass burning: Reactive chlorine emissions inventory, J. Geophys. Res., 104, 8373-8389, 1999.

Mahieu, E., Zander, R., Delbouille, L., Demoulin, P., Roland, G., and Servais, C.: Observed trends in total vertical column abundances of atmospheric gases from IR solar spectra recorded at the Jungfraujoch, J. Atmos. Chem., 28, 227-243, 1997.

Manning, M. R., Lowe, D. C., Moss, R. C., Bodeker, G. E., and Allan, W.: Short-term variations in the oxidizing power of the atmosphere, Nature, 436, doi:10.1038/nature03900, 2005.

Mickley, L. J., Abbatt, J. P. D., Frederick, J. E., and Russell III, J. M.: Response of summertime odd nitrogen and ozone at $17 \mathrm{mbar}$ to Mount Pinatubo aerosol over the southern midlatitudes: Observations from the Halogen Occultation Experiment, J. Geophys. Res., 102(D19), 23 573-23 582, 1997.

Newell, R. E. and Evans, M. J.: Seasonal changes in pollutant transport to the North Pacific: the relative importance of Asian and European sources, Geophys. Res. Lett., 27, 2509-2512, 2000.

Novelli, P. C., Steele, L. P., and Tans, P. P.: Mixing ratios of carbon monoxide in the troposphere, J. Geophys. Res., 102(D18),
12 855-12 861, 1992.

Novelli, P. C., Masarie, K. A., Tans, P. P., and Lang, P. M.: Recent changes in atmospheric carbon monoxide, Science, 263, 1587$1590,1994$.

Novelli, P. C., Masarie, K. A., and Lang, P. M.: Distributions and recent changes in carbon monoxide in the lower troposphere, $\mathrm{J}$. Geophys. Res., 103(D15), 19015-19033, 1998.

Novelli, P. C., Masarie, K. A., Lang, P. M., Hall, B. D., Myers, R. C., and Elkins, J. W.: Reanalysis of tropospheric CO trends: Effects of the 1997-1998 wildfires, J. Geophys. Res., 108(D15), 4464, doi:10.1029/2002JD003031, 2003.

Prinn, R., Huang, J., Weiss, R. F., et al.: Evidence for variability of atmospheric hydroxyl radicals over the past quarter century, Geophys. Res. Lett., 32, L07809, doi:10.1029/2004GL022228, 2005.

Rinsland, C. P., Jones, N. B., Connor, B. J., et al.: Northern and southern hemisphere ground-based infrared spectroscopic measurements of tropospheric carbon monoxide and ethane, J. Geophys. Res., 103(D21), 28 197-28 218, doi:10.1029/98JD02515, 1998.

Rinsland, C. P., Goldman, A., Murcray, F. J., et al.: Infrared solar spectroscopic measurements of free tropospheric $\mathrm{CO}, \mathrm{C}_{2} \mathrm{H}_{6}$, and $\mathrm{HCN}$ above Mauna Loa, Hawaii: Seasonal variations and evidence for enhanced emissions from the Southeast Asian tropical fires of 1997-1998, J. Geophys. Res., 104(D15), 18 667-18 680, doi:10.1029/1999JD900366, 1999.

Rinsland, C. P., Mahieu, E., Zander, R., Demoulin, P., Forrer, J., and Buchmann, B.: Free tropospheric $\mathrm{CO}, \mathrm{C}_{2} \mathrm{H}_{6}$, and $\mathrm{HCN}$ above central Europe: Recent measurements from the Jungfraujoch station including the detection of elevated columns during 1998, J. Geophys. Res., 105, 24 235-24 249, 2000.

Schubert, S. D., Rood, R. B., and Pfaendtner, J.: An assimilated data set for earth science applications, B. Am. Meteorol. Soc., 74, 2331-2342, 1993.

Spivakovsky, C. M., Logan, J. A., Montzka, S. A., Balkanski, Y. J., Foremen-Fowler, M., Jones, D. B. A., Horowitz, L. W., Brenninkmeijer, C. A. M., Prather, M. J., Wofsy, S. C., and McElroy, M. B.: Three dimensional climatological distribution of tropospheric OH: update and evaluation, J. Geophys. Res., 105, 89318980, 2000.

Stohl, A., Eckhardt, S., Forster, C., James, P., and Spichtinger, $\mathrm{N}$.: On the pathways and timescales of intercontinental air pollution transport, J. Geophys. Res., 107(D23), doi:10.1029/2001JD001396, 2002.

Stolarski, R. S. and Frith, S. M.: Search for evidence of trend slowdown in the long-term TOMS/SBUV total ozone data record: the importance of instrument drift uncertainty, Atmos. Chem. Phys., 6, 4057-4065, 2006, http://www.atmos-chem-phys.net/6/4057/2006/.

Takacs, L. L., Molod, A., and Wang, T.: Documentation of the Goddard Earth Observing System (GEOS) General Circulation Model - Version 1, NASA Technical Memorandum, 104606, 1, 1994.

Wotawa, G., Novelli, P., Trainer, M., and Granier, C.: Inter-Annual Variability of Summertime CO Concentrations in the Northern Hemisphere Explained by Boreal Forest Fires in North America and Russia, Geophys. Res. Lett., 28(24), 4575-4578, 2001.

WMO (World Meteorological Organization): Scientific Assessment of Ozone Depletion: 2006, Global Ozone Research and 
Monitoring Project - Report No. 50, 572 pp., Geneva, Switzerland, 2007.

Yevich, R. and Logan, J. A.: An assessment of biofuel use and burning of agricultural waste in the developing world, Global Biogeochem. Cy., 17 (4), 1095, doi:10.1029/2002GB001952, 2003.

Yurganov, L. N., Grechko, E. I., and Dzhola, A. V.: Variations of carbon monoxide density in the total atmospheric column over Russia between 1970 and 1995: Upward trend and disturbances, attributed to the influence of volcanic aerosol and forest fires, Geophys. Res. Lett., 24, 1231-1234, 1997.

Yurganov, L. N., Grechko, E. I., and Dzhola, A. V.: Zvenigorod carbon monoxide total column time series: $27 \mathrm{yr}$ of measurements, Chemosphere, 1, 127-136, 1999.
Zander, R., Demoulin, Ph., Ehhalt, D. H., Schmidt, U., and Rinsland, C. P.: Secular increase of the total vertical column abundance of carbon monoxide above central Europe since 1950, J. Geophys. Res., 94, 11 021-11 028, 1989.

Zhao, Y., Kondo, Y., Murcray, F. J., Liu, X., Koike, M., Irie, H., Strong, K., Suzuki, K., Sera, M., and Ikegami, Y.: Seasonal variations of HCN over northern Japan measured by ground-based infrared solar spectroscopy, Geophys. Res. Lett., 27(14), 2085 , 2000.

Ziemke, J. R., Chandra, S., McPeters, R. D., and Newman, P. A.: Dynamical proxies of column ozone with applications to global trend models, J. Geophys. Res., 102(D5), 6117-6129, 1997. 